\title{
Article \\ Effect of Small Amount of Ni Addition on Microstructure and Fatigue Properties of Sn-Sb-Ag Lead-Free Solder
}

\author{
Mizuki Yamamoto ${ }^{1}$, Ikuo Shohji ${ }^{1, *}$, Tatsuya Kobayashi ${ }^{1}\left(\mathbb{D}\right.$, Kohei Mitsui $^{2}$ and Hirohiko Watanabe ${ }^{1,2}$ \\ 1 Graduate School of Science and Technology, Gunma University, Kiryu 3768515, Japan; \\ t201b095@gunma-u.ac.jp (M.Y.); kobayashi.t@gunma-u.ac.jp (T.K.); \\ watanabe-hirohiko@fujielectric.com (H.W.) \\ 2 Production Technology Development Section, Fuji Electric Co., Ltd., Hino 1918502, Japan; \\ mitsui-kouhei@fujielectric.com \\ * Correspondence: shohji@gunma-u.ac.jp; Tel.: +81-277-30-1544
}

check for updates

Citation: Yamamoto, M.; Shohji, I.; Kobayashi, T.; Mitsui, K.; Watanabe, H. Effect of Small Amount of Ni Addition on Microstructure and Fatigue Properties of $\mathrm{Sn}-\mathrm{Sb}-\mathrm{Ag}$ Lead-Free Solder. Materials 2021, 14, 3799. https://doi.org/10.3390/ ma14143799

Academic Editor: Sergey V.

Konovalov

Received: 30 May 2021

Accepted: 6 July 2021

Published: 7 July 2021

Publisher's Note: MDPI stays neutral with regard to jurisdictional claims in published maps and institutional affiliations.

Copyright: (c) 2021 by the authors. Licensee MDPI, Basel, Switzerland. This article is an open access article distributed under the terms and conditions of the Creative Commons Attribution (CC BY) license (https:// creativecommons.org/licenses/by/ $4.0 /)$.

\begin{abstract}
The effect of the addition volume of Ni on the microstructures and tensile and fatigue properties of Sn-6.4Sb-3.9Ag (mass \%) was investigated using micro-size specimens. The addition of $\mathrm{Ni}$ into $\mathrm{Sn}-6.4 \mathrm{Sb}-3.9 \mathrm{Ag}$ tends to increase the number of grains formed in the solidification process and produce a high-angle grain boundary. An amount of $0.1 \%$ proof stress of Sn-6.4Sb-3.9Ag decreases with an increase in the $\mathrm{Ni}$ addition volume at a strain rate of $2.0 \times 10^{-1} \mathrm{~s}^{-1}$. The effect of the addition of $\mathrm{Ni}$ into $\mathrm{Sn}-6.4 \mathrm{Sb}-3.9 \mathrm{Ag}$ on tensile strength is negligible at both $25^{\circ} \mathrm{C}$ and $175^{\circ} \mathrm{C}$. The elongation of Sn-6.4Sb-3.9Ag decreases with an increase in the Ni addition volume at $25^{\circ} \mathrm{C}$ according to the fracture mode change from ductile chisel point fracture to shear fracture. The effect of the addition of $\mathrm{Ni}$ into $\mathrm{Sn}-6.4 \mathrm{Sb}-3.9 \mathrm{Ag}$ on the elongation is negligible at $175^{\circ} \mathrm{C}$. The low cycle fatigue test result shows that the fatigue life does not degrade even at $175{ }^{\circ} \mathrm{C}$ in all alloys investigated. The fatigue life of Sn-6.4Sb-3.9Ag-0.4Ni (mass\%) is superior to those of Sn-6.4Sb-3.9Ag and Sn-6.4Sb-3.9Ag-0.03Ni (mass\%) in the high cycle fatigue area. The electron back scattering diffraction (EBSD) analysis result shows that fine recrystallized grains are generated at the cracked area in Sn-6.4Sb-3.9Ag-0.4Ni in the fatigue test at $175^{\circ} \mathrm{C}$, and the crack progresses in a complex manner at the grain boundaries.
\end{abstract}

Keywords: Sn-6.4Sb-3.9Ag; lead-free solder; Ni addition; microstructure; tensile properties; low cycle fatigue properties; EBSD analysis

\section{Introduction}

Since the restriction of hazardous substances (RoHS) directive was enforced in the European Union (EU) in 2006, the use of lead-containing solder in electrical and electric equipment has been regulated and thus lead-free solder such as $\mathrm{Sn}-\mathrm{Ag}-\mathrm{Cu}, \mathrm{Sn}-\mathrm{Cu}$, and $\mathrm{Sn}-\mathrm{Bi}$ alloys has been used [1]. Currently, Sn-Ag-Cu alloys such as Sn-3.0Ag-0.5Cu (mass\%) and $\mathrm{Sn}-3.5 \mathrm{Ag}-0.7 \mathrm{Cu}$ (mass\%) are mainly used for the assembly of electronics parts [2,3]. In the soldering process, solder is melted by heating, and molten solder wets the electrode of the electronics parts. After molten solder reacts with the electrode materials by the interdiffusion of constituent atoms, the joint is formed by the solidification of molten solder. Thus, many studies of the wettability of molten lead-free solder have been conducted [4-6]. Additionally, as the reliability of the soldered joint, the thermal fatigue resistance, the heat resistance and ion migration resistance are very important. Then, there are many studies for fatigue [7,8], thermal fatigue [9-11], interfacial reaction (growth of intermetallic compounds) [12-14], creep [15,16] and ion migration [17,18] of various lead-free solder. In particular, reliable thermal fatigue properties of the solder joint are among the most important factors under operating conditions. Moreover, finite element analysis of the electronics products is usually conducted to design the joint and predict its reliability. Various mechanical properties of the solder are required to conduct finite element analysis, 
and thus many studies on the mechanical properties of various lead-free solder have been conducted [19-21].

For the die attach material of the power semiconductor, lead-rich solder has been used due to its excellent thermal fatigue resistance. Although the lead-rich solder applied to some products is currently excluded from the RoHS directive, lead-free materials are expected to be applied to them in the future. In addition, Si has been used for the power semiconductor or $\mathrm{SiC}$ and $\mathrm{GaN}$ are expected to be next-generation semiconductors as such semiconductors can operate at a higher temperature and frequency, and with lower energy. In such next-generation semiconductors, operation temperature and surrounding environmental temperature are higher and thus the die attach materials must have improved thermal fatigue resistance. Therefore, various lead-free solders with higher solidus and liquidus temperatures than the Sn-Ag-Cu solder [22-27] and various nanopaste [28-31] have been researched to develop die attach materials with excellent thermal fatigue resistance.

We focused on $\mathrm{Sn}$-Sb system alloys as high-temperature lead-free solder and investigated their mechanical properties and microstructures [24-26]. In particular, fatigue properties at temperatures ranging from $25^{\circ} \mathrm{C}$ to $200{ }^{\circ} \mathrm{C}$ were investigated using micro-size specimens [8]. As a result, it was clarified that the addition of a small amount of $\mathrm{Ni}$ and Ge into the Sn-6.4Sb-3.9Ag (mass\%) ternary peritectic-eutectic alloy can slightly improve the fatigue life of the alloy [26]. Moreover, it was already reported that the addition of a small amount of $\mathrm{Ni}$ and Ge into several lead-free solder improves the wettability of molten solder to the $\mathrm{Cu}$ plate [6]. In a previous study [26], the addition volume of Ge was very small ( 0.003 mass $\%)$ compared with that of $\mathrm{Ni}(0.25$ mass $\%)$. Since the addition of Ge is effective to suppress the generation of the dross of solder and improve the wettability of the molten solder [32], it seems that the addition of $\mathrm{Ni}$ has a great effect on improving the mechanical properties of the alloy.

Therefore, the aim of this study is to investigate the effect of the addition volume of a small amount of $\mathrm{Ni}$ was investigated on microstructures, tensile properties and fatigue properties of Sn-6.4Sb-3.9Ag using micro-size specimens.

\section{Materials and Methods}

In this study, three kinds of Sn-Sb-Ag system lead-free solder were prepared. Table 1 shows their chemical compositions and melting properties. Melting properties were investigated by the differential scanning calorimetry method on the basis of JIS Z 3198-1 [33].

Micro-size specimens were fabricated by Kariya's method [8]. The shape and dimensions of the micro-size specimen are indicated in Figure 1. The fabrication flow of the specimen is shown in Figure 2. Solder wire with $1.2 \mathrm{~mm}$ diameter for each alloy was prepared. As-cast dog-bone type micro-size specimens were fabricated with solder wire using a divided mold. The gage length and the diameter of the specimen were $2 \mathrm{~mm}$ and $0.5 \mathrm{~mm}$, respectively. Casting was conducted with a hot plate at a temperature which is $30{ }^{\circ} \mathrm{C}$ higher than the liquidus temperature of each solder. The cooling rate in the solidification process was controlled by removing the metal mold with the specimen from the hot plate and promptly cooling it on the stainless plate. The cooling rates of $\mathrm{Sn}-6.4 \mathrm{Sb}-3.9 \mathrm{Ag}$, Sn-6.4Sb-3.9Ag-0.03Ni and Sn-6.4Sb-3.9Ag-0.4Ni in solidification were $3.0^{\circ} \mathrm{C} / \mathrm{s}, 2.2^{\circ} \mathrm{C} / \mathrm{s}$ and $2.5^{\circ} \mathrm{C} / \mathrm{s}$, respectively. Figure 3 shows the appearance of the micro-size specimen.

Table 1. Chemical compositions and melting properties of alloys used in this study.

\begin{tabular}{ccc}
\hline $\begin{array}{c}\text { Chemical Composition } \\
\text { [Mass\%] }\end{array}$ & $\begin{array}{c}\text { Solidus } \\
\text { Temperature }\left[{ }^{\circ} \mathbf{C}\right]\end{array}$ & $\begin{array}{c}\text { Liquidus } \\
\text { Temperature }\left[{ }^{\circ} \mathbf{C}\right]\end{array}$ \\
\hline Sn-6.4Sb-3.9Ag & 230.4 & 234.8 \\
\hline Sn-6.4Sb-3.9Ag-0.03Ni & 225.3 & 234.3 \\
\hline Sn-6.4Sb-3.9Ag-0.4Ni & 226.3 & 233.8 \\
\hline
\end{tabular}




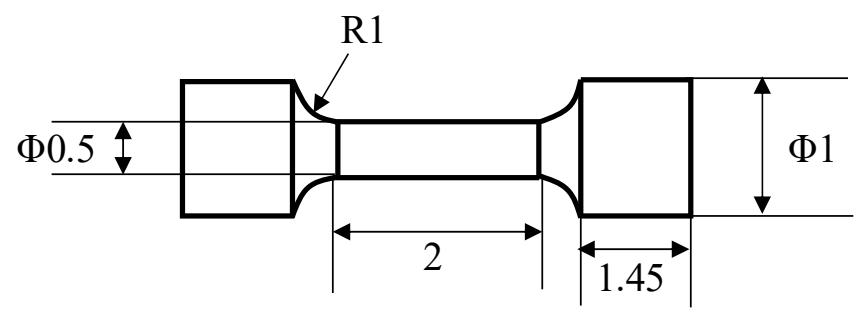

Figure 1. Shape and dimensions of micro-size specimen ( $\Phi$ : diameter; unit: $\mathrm{mm}$ ).

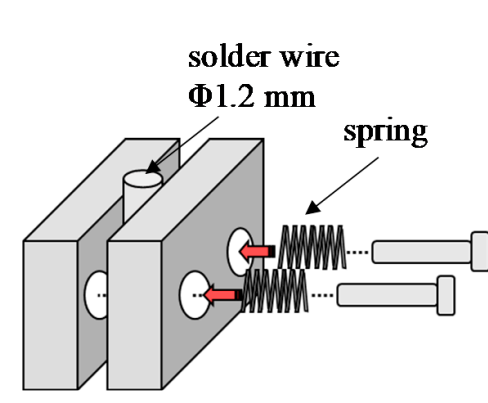

insert wire in divided metal mold

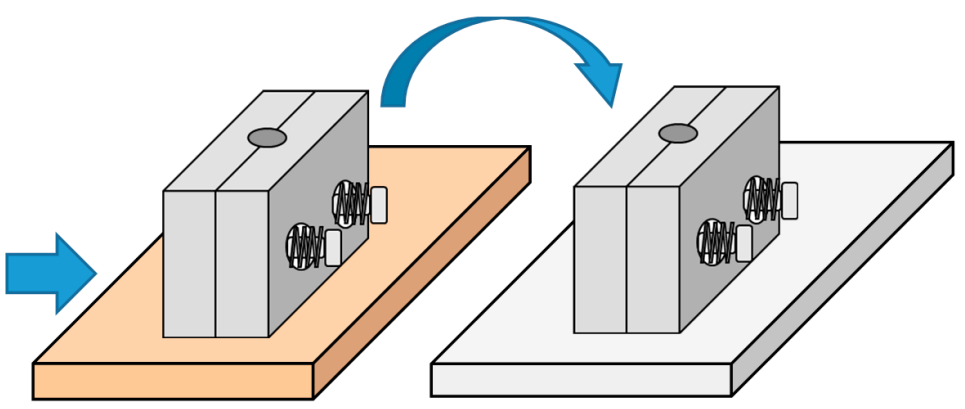

cool the mold with

put the mold on a hot plate to melt solder at the temperature that is $30^{\circ} \mathrm{C}$ higher than the liquidus temperature of solder on the stainless plate

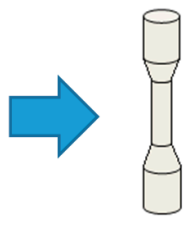

take the specimen from the mold

Figure 2. Fabrication flow of micro-size specimen.

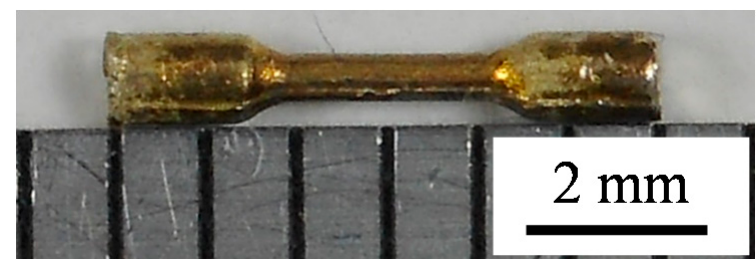

Figure 3. Appearance of micro-size specimen (Sn-6.4Sb-3.9Ag-0.4Ni).

A tensile test was carried out at a strain rate ranging from $2.0 \times 10^{-3} \mathrm{~s}^{-1}$ to $2.0 \times 10^{-1} \mathrm{~s}^{-1}$ at $25^{\circ} \mathrm{C}$ and $175^{\circ} \mathrm{C}$ using a microload test system (LMH207-10, SAGINOMIYA SEISAKUSHO, Inc., Tokyo, Japan). Five specimens were tested under each condition and tensile strength, $0.1 \%$ proof stress and elongation after fracture were investigated. Fractured specimens were observed with a field emission scanning electron microscope (FE-SEM) (S-4300SE, Hitachi High-Tech Science, Inc., Tokyo, Japan) after the tensile test. A low cycle fatigue test was also carried out by displacement control with the microload test system. The fatigue test was performed at a strain rate of $2.0 \times 10^{-3} \mathrm{~s}^{-1}$ and temperatures of $25^{\circ} \mathrm{C}$ and $175^{\circ} \mathrm{C}$. Displacement was controlled by a symmetrical triangle wave. The total strain range, $\Delta \varepsilon_{\mathrm{t}}$ was controlled in the range of $0.5 \%$ to $2.5 \%$. The fatigue life in this study was defined as a cycle number in which the maximum load was decreased by $20 \%$ compared with that at five cycles. To investigate the microstructures of the specimens before and after the fatigue test, the specimens were polished by \#500-\#4000 waterproof abrasive papers and subsequently polished with $1 \mu \mathrm{m}$ alumina powder suspension. Thereafter, sputter etching by Ar milling was applied to the polished surfaces using a cross section milling machine (IB-19530CP, JEOL Ltd., Tokyo, Japan). An electron backscattering diffraction (EBSD) analysis was conducted on the specimen after Ar milling to investigate fatigue damage behavior using an EBSD system (TSL MSC-2200, TexSEM Laboratories, Inc., Provo, UT, USA) equipped with the FE-SEM. The rolling direction and the normal direction were set to the longitudinal direction of the specimen and the normal direction to the plane parallel to the longitudinal direction, respectively. In the EBSD analysis, Kikuchi lines of $\beta$-Sn 
were detected. The inverse pole figure (IPF) map and the grain boundary (GB) map were investigated. In this study, the grain boundary with a crystal orientation difference from $2^{\circ}$ to $15^{\circ}$ was defined as the low-angle grain boundary, and that with a crystal orientation difference from $15^{\circ}$ to $180^{\circ}$ was defined as the high-angle grain boundary. For the initial microstructure, the microstructural observation was also conducted with an electron probe X-ray microanalyzer (EPMA) (EPMA-1610, Shimadzu Corp., Kyoto, Japan).

\section{Results and Discussion}

\subsection{Initial Microsturutures}

Figure 4 shows the result of the mapping analysis for the cross section of the ascast $\mathrm{Sn}-6.4 \mathrm{Sb}-3.9 \mathrm{Ag}-0.4 \mathrm{Ni}$ micro-size specimen using the EPMA. The phase diagram of Sn-6.4Sb-3.9Ag-xNi calculated by Thermo-Calc 2017a (Thermo-Calc Software AB, Solna, Sweden) [34] is shown in Figure 5. In the backscattered electron (BSE) image, bright gray areas and dark gray areas are observed. $\mathrm{Sn}$ and $\mathrm{Sb}$ are detected in the bright gray area and $\mathrm{Ag}$ and $\mathrm{Sn}$ are detected in the dark gray area in Figure 4. Ni is condensed in some areas. Considering the EPMA mapping analysis and the phase diagram of $5 n-6.4 \mathrm{Sb}-3.9 \mathrm{Ag}-\mathrm{xNi}$, $\mathrm{SbSn}, \mathrm{Ag}_{3} \mathrm{Sn}$ and a small amount of $\mathrm{SbNi}$ seem to be dispersed in the $\beta$-Sn matrix. A similar microstructure was observed in the Sn-6.4Sb-3.9Ag-0.03Ni micro-size specimen although only a small amount of condensation of Ni was observed. Figure 6 shows optical microscope images of micro-size specimens. Similar micrographs to the BSE image shown in Figure 4 can be observed. It seems that the eutectic microstructure of $\beta-\mathrm{Sn}$ and $\mathrm{Ag}_{3} \mathrm{Sn}$ is formed to surround the $\beta$-Sn dendrite phases. Compared with the images of $\mathrm{Sn}-6.4 \mathrm{Sb}$ 3.9Ag and $\mathrm{Sn}-6.4 \mathrm{Sb}-3.9 \mathrm{Ag}-0.03 \mathrm{Ni}$, the size of primary $\beta$-Sn phases is analogous, although a few inferred phases of SbNi are observed in the image of Sn-6.4Sb-3.9Ag-0.03Ni. In contrast, coarse primary $\beta$-Sn phases are formed in Sn-6.4Sb-3.9Ag-0.4Ni compared with other alloys. This means that the addition of $0.4 \% \mathrm{Ni}$ promotes the coarsening primary $\beta$-Sn phases.

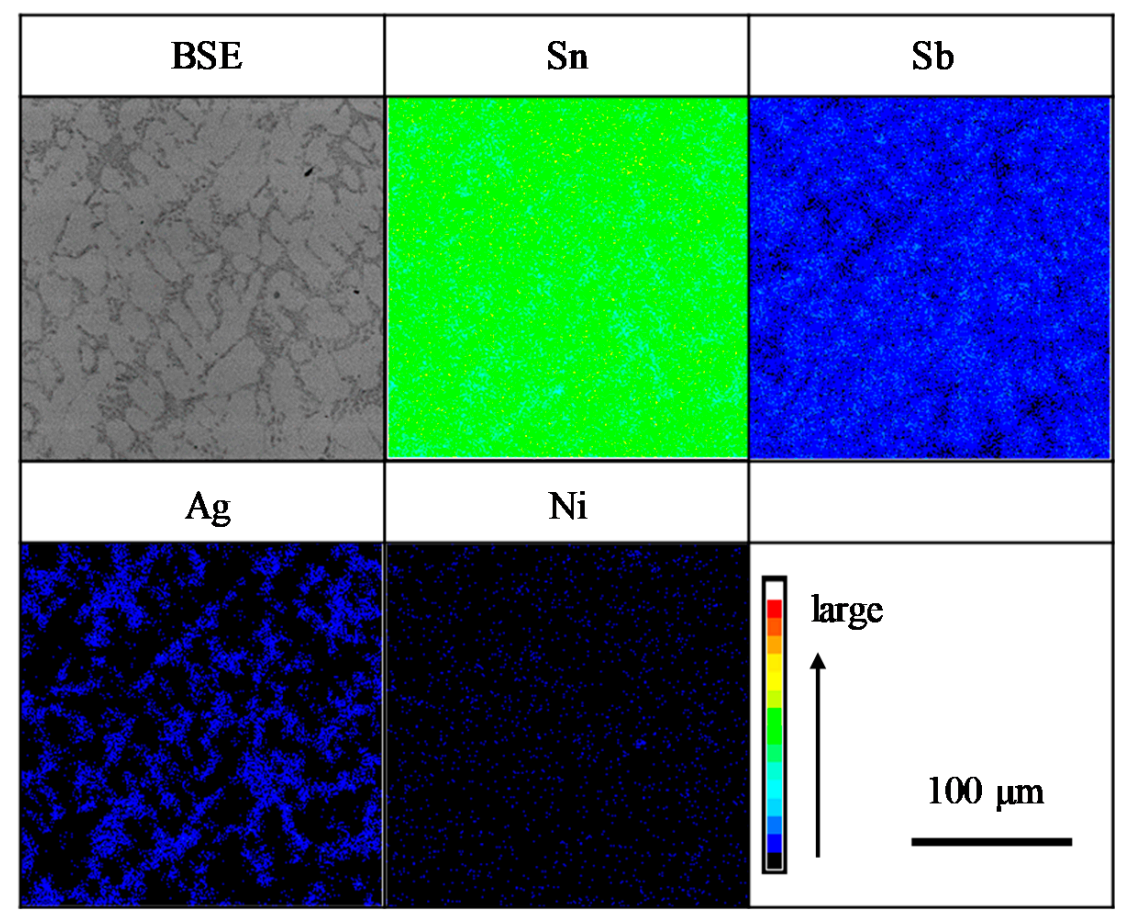

Figure 4. Result of mapping analysis for backscattered electron (BSE) image of as-cast Sn-6.4Sb3.9Ag-0.4Ni micro-size specimen with electron probe X-ray microanalyzer (EPMA). 


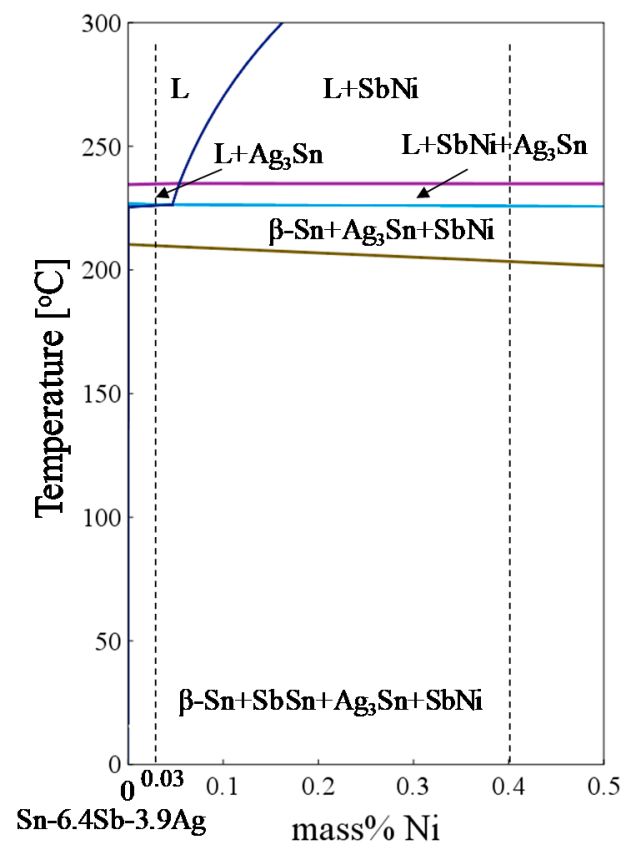

Figure 5. Phase diagram of Sn-6.4Sb-3.9Ag-xNi calculated by Thermo-Calc 2017a.

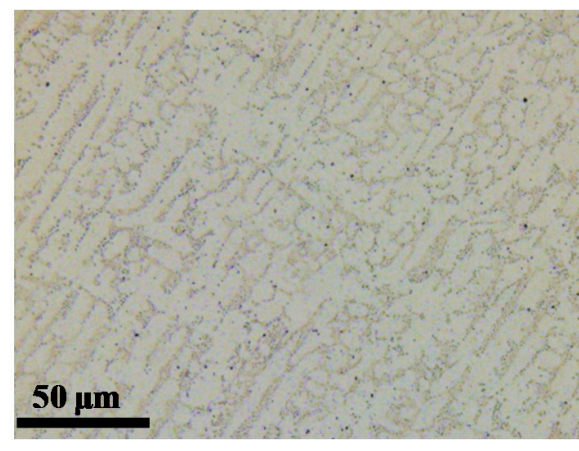

(a)

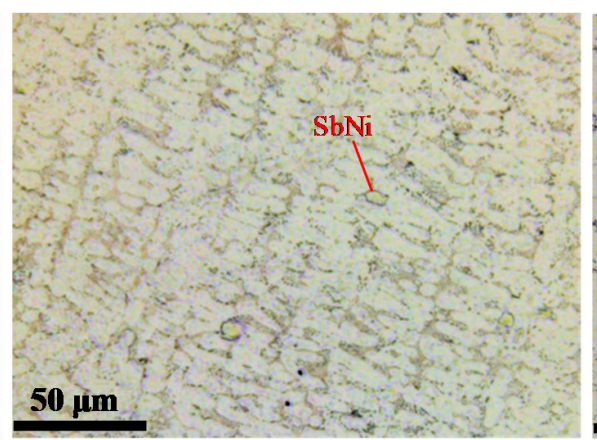

(b)

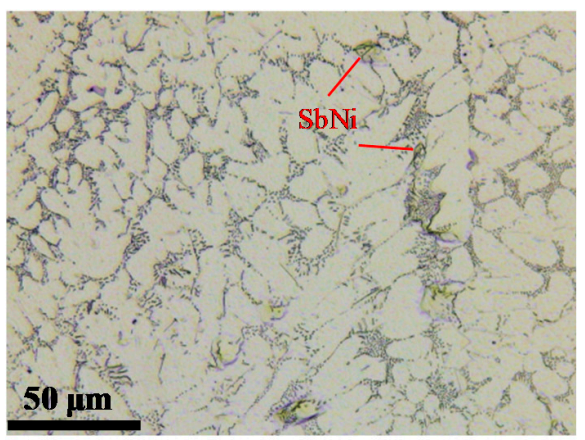

(c)

Figure 6. Optical microscope images of Sn-6.4Sb-3.9Ag (a), Sn-6.4Sb-3.9Ag-0.03Ni (b) and Sn-6.4Sb-3.9Ag-0.4Ni (c). The horizontal direction in the figure corresponds to the longitudinal direction of the specimen.

Figure 7 shows EBSD analysis results for as-cast microstructures of Sn-6.4Sb-3.9Ag [26], Sn-6.4Sb-3.9Ag-0.03Ni and Sn-6.4Sb-3.9Ag-0.4Ni alloys. In the micro-size specimens, there are one or, at most, a few grains in the cross section, which is perpendicular to the longitudinal direction [8]. In the Sn-6.4Sb-3.9Ag alloy, there are two grains with a low-angle grain boundary [26]. As shown in Figure $7 \mathrm{~b}$, although two grains are also observed in the $\mathrm{Sn}-6.4 \mathrm{Sb}-3.9 \mathrm{Ag}-0.03 \mathrm{Ni}$ alloy, the grain boundary changes to a high-angle grain boundary. Moreover, in the Sn-6.4Sb-3.9Ag-0.4Ni alloy shown in Figure 7c, three grains with highangle grain boundaries are observed. From these results, it was found that the addition of $\mathrm{Ni}$ into $\mathrm{Sn}-6.4 \mathrm{Sb}-3.9 \mathrm{Ag}$ tends to increase the number of grains and form a high-angle grain boundary. This is due to the fact that Ni works as a nucleation site in the solidification process and increases the grain number. 


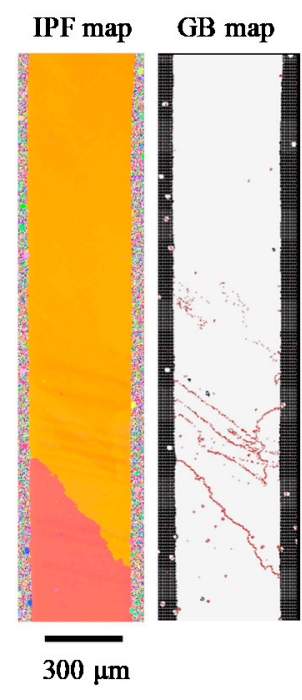

(a)

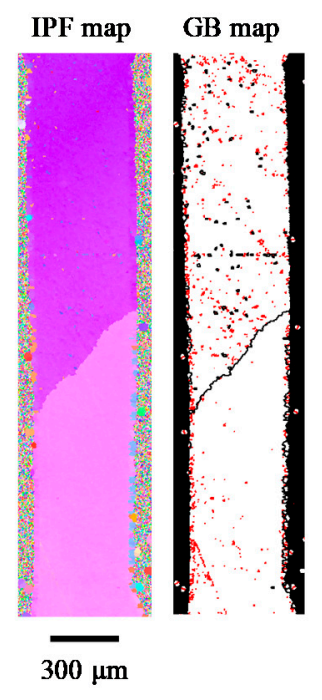

(b)

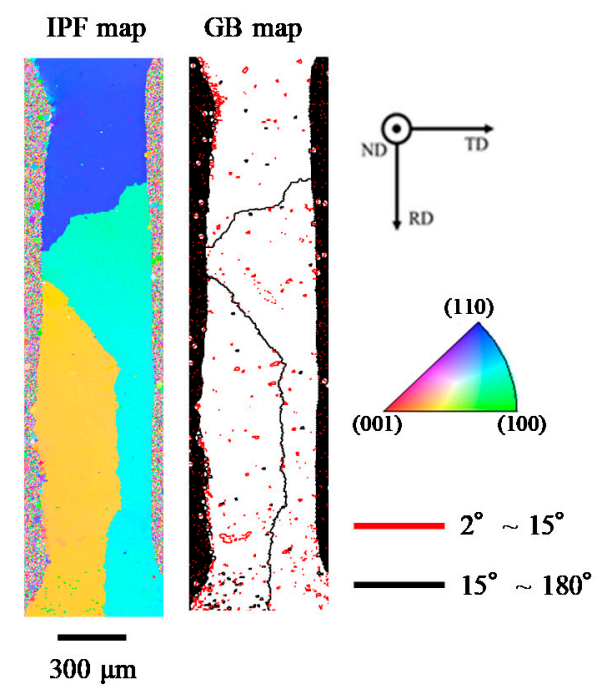

(c)

Figure 7. Electron backscattering diffraction (EBSD) analysis results of initial microstructures of Sn-6.4Sb-3.9Ag [26] (a), Sn-6.4Sb-3.9Ag-0.03Ni (b) and Sn-6.4Sb-3.9Ag-0.4Ni (c).

\subsection{Effect of Ni Addition on Tensile Properties of Sn-6.4Sb-3.9Ag}

Figure 8 shows the tensile properties investigated using micro-size specimens. The results of Sn-6.4Sb-3.9Ag are quoted from our previous study [26]. The $0.1 \%$ proof stress of Sn-6.4Sb-3.9Ag increases with an increasing strain rate at $25^{\circ} \mathrm{C}$. A similar tendency is found in the Sn-6.4Sb-3.9Ag with the addition of a small amount of $\mathrm{Ni}$ when the strain rate is less than $2.0 \times 10^{-2} \mathrm{~s}^{-1}$. However, the $0.1 \%$ proof stress of the $\mathrm{Sn}-6.4 \mathrm{Sb}-3.9 \mathrm{Ag}$ decreases with the increase in the Ni addition volume at a strain rate of $2.0 \times 10^{-1} \mathrm{~s}^{-1}$. As shown in Figure 7, the high-angle grain boundary is generated in the specimen by the addition of $\mathrm{Ni}$. Then, the grains with various Schmidt factors form in the Ni containing Sn-6.4Sb-3.9Ag alloys. For example, in Figure $7 \mathrm{~b}$, the Schmidt factors of the upper grain and the lower grain were 0.40 and 0.15 , respectively. The Schmidt factor of the upper grain was 0.1 , and those of other grains were 0.35, as shown in Figure 7c. In the specimen in which a grain with a high Schmidt factor formed, plastic deformation easily took place. Thus, it is possible that the grain with a high Schmidt factor was easily deformed, and the proof stress decreased at a high strain rate in the Ni containing Sn-6.4Sb-3.9Ag alloys. At $175^{\circ} \mathrm{C}$, the $0.1 \%$ proof stress increased with an increase in strain rate in all alloys investigated, although the $0.1 \%$ proof stress at $175^{\circ} \mathrm{C}$ was smaller than that at $25^{\circ} \mathrm{C}$.

As shown in Figure 8b, it was found that the tensile strength of Sn-6.4Sb-3.9Ag increases with an increase in the strain rate regardless of the temperature. The effect of the addition of $\mathrm{Ni}$ into $\mathrm{Sn}-6.4 \mathrm{Sb}-3.9 \mathrm{Ag}$ on the tensile strength is negligible. The tensile strength of all alloys at $175^{\circ} \mathrm{C}$ was approximately one-third of those at $25^{\circ} \mathrm{C}$.

For elongation, a clear relation was not seen between the strain rate and the elongation considering the large dispersion of the data. The elongation generally tended to improve with the increase in temperature, although the dispersion of the data was relative large. At $25^{\circ} \mathrm{C}$, the average of the elongation decreased with the increase in the Ni addition volume, although the decrease in $\mathrm{Sn}-6.4 \mathrm{Sb}-3.9 \mathrm{Ag}-0.03 \mathrm{Ni}$ was small. Figure 9 shows general views of ruptured specimens by the tensile test at a strain rate of $2.0 \times 10^{-1} \mathrm{~s}^{-1}$. At $25^{\circ} \mathrm{C}$, the chisel point fracture was observed in Sn-6.4Sb-3.9Ag and Sn-6.4Sb-3.9Ag-0.03Ni. In contrast, shear fracture was observed in Sn-6.4Sb-3.9Ag-0.4Ni. This fracture mode change from ductile chisel point fracture to shear fracture caused a decrease in the elongation with the increase in the $\mathrm{Ni}$ addition volume. At $175^{\circ} \mathrm{C}$, a ductile chisel line fracture was observed, regardless of alloy types. Therefore, it seems that the meaningful differences were not observed in the elongation of the investigated alloys at $175^{\circ} \mathrm{C}$ since the fracture mode did not change. 


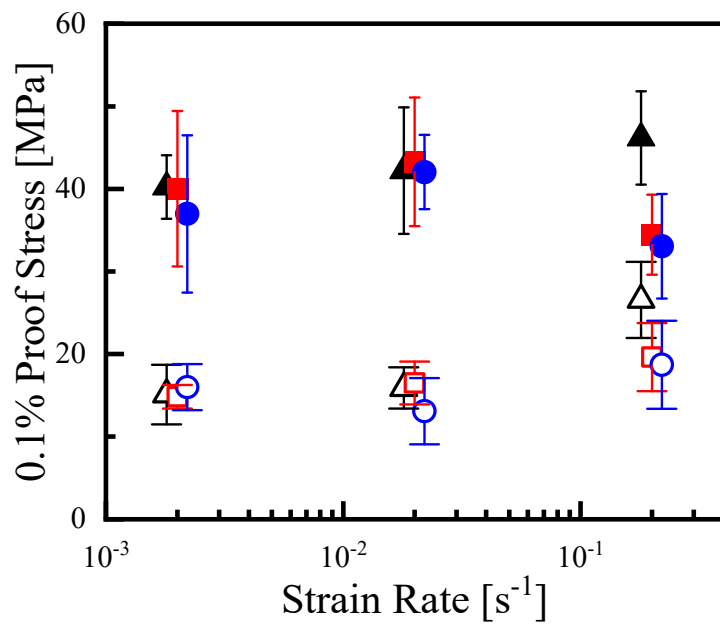

A $\mathrm{SnSbAg} 25^{\circ} \mathrm{C}$ [26]

$\triangle$ SnSbAg $175^{\circ} \mathrm{C}[26]$

- $\mathrm{SnSbAg}-0.03 \mathrm{Ni} 25^{\circ} \mathrm{C}$

$\square \mathrm{SnSbAg}-0.03 \mathrm{Ni} 175^{\circ} \mathrm{C}$

$\mathrm{SnSbAg}-0.4 \mathrm{Ni} 25^{\circ} \mathrm{C}$

O SnSbAg-0.4Ni $175^{\circ} \mathrm{C}$

(a)

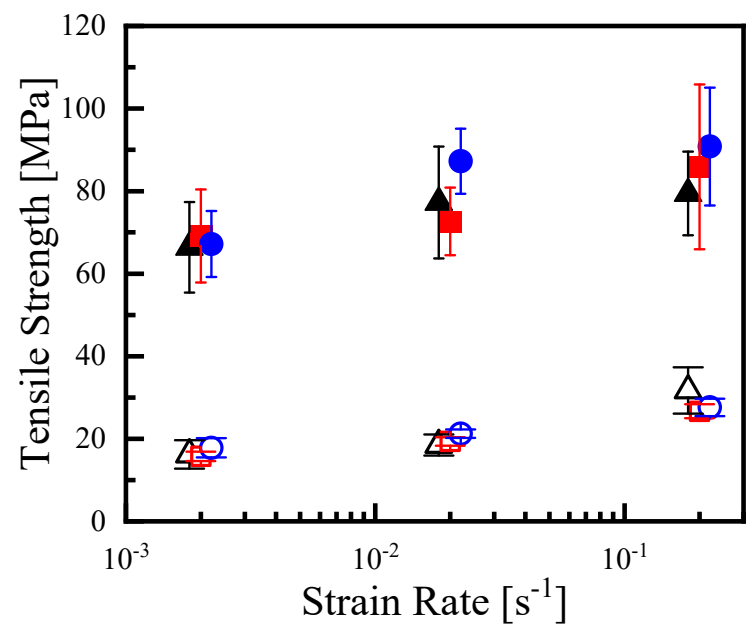

$\Delta \mathrm{SnSbAg} 25^{\circ} \mathrm{C}$ [26]

$\triangle$ SnSbAg $175^{\circ} \mathrm{C}[26]$

- SnSbAg-0.03Ni $25^{\circ} \mathrm{C}$

$\square \mathrm{SnSbAg}-0.03 \mathrm{Ni} 175^{\circ} \mathrm{C}$

- $\mathrm{SnSbAg}-0.4 \mathrm{Ni} 25^{\circ} \mathrm{C}$

O SnSbAg-0.4Ni $175^{\circ} \mathrm{C}$

(b)

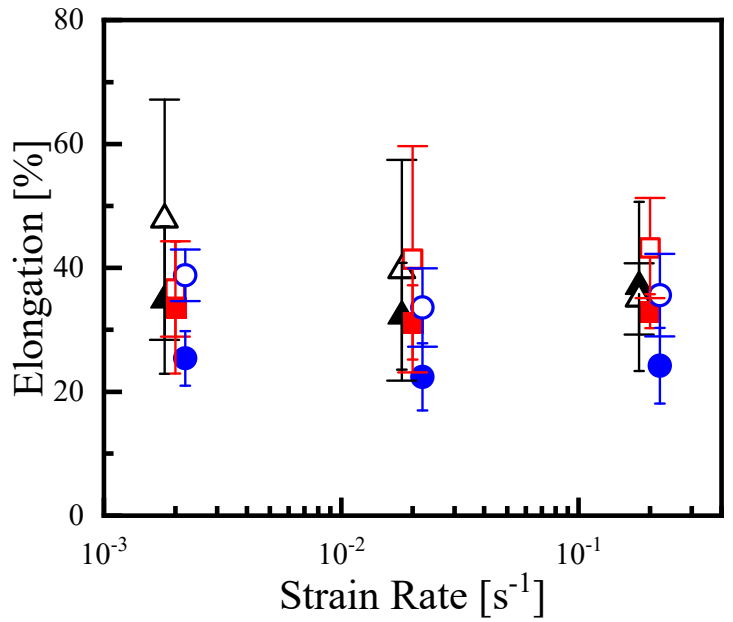

A $\mathrm{SnSbAg} 25^{\circ} \mathrm{C}[26]$

$\triangle \mathrm{SnSbAg} 175^{\circ} \mathrm{C}[26]$

- SnSbAg-0.03Ni $25^{\circ} \mathrm{C}$

$\square \mathrm{SnSbAg}-0.03 \mathrm{Ni} 175^{\circ} \mathrm{C}$

SnSbAg-0.4Ni $25^{\circ} \mathrm{C}$

O SnSbAg-0.4Ni $175{ }^{\circ} \mathrm{C}$

(c)

Figure 8. Tensile properties of Sn-6.4Sb-3.9Ag [26], Sn-6.4Sb-3.9Ag-0.03Ni and Sn-6.4Sb-3.9Ag-0.4Ni. (a) $0.1 \%$ proof stress; (b) tensile strength; (c) elongation. 


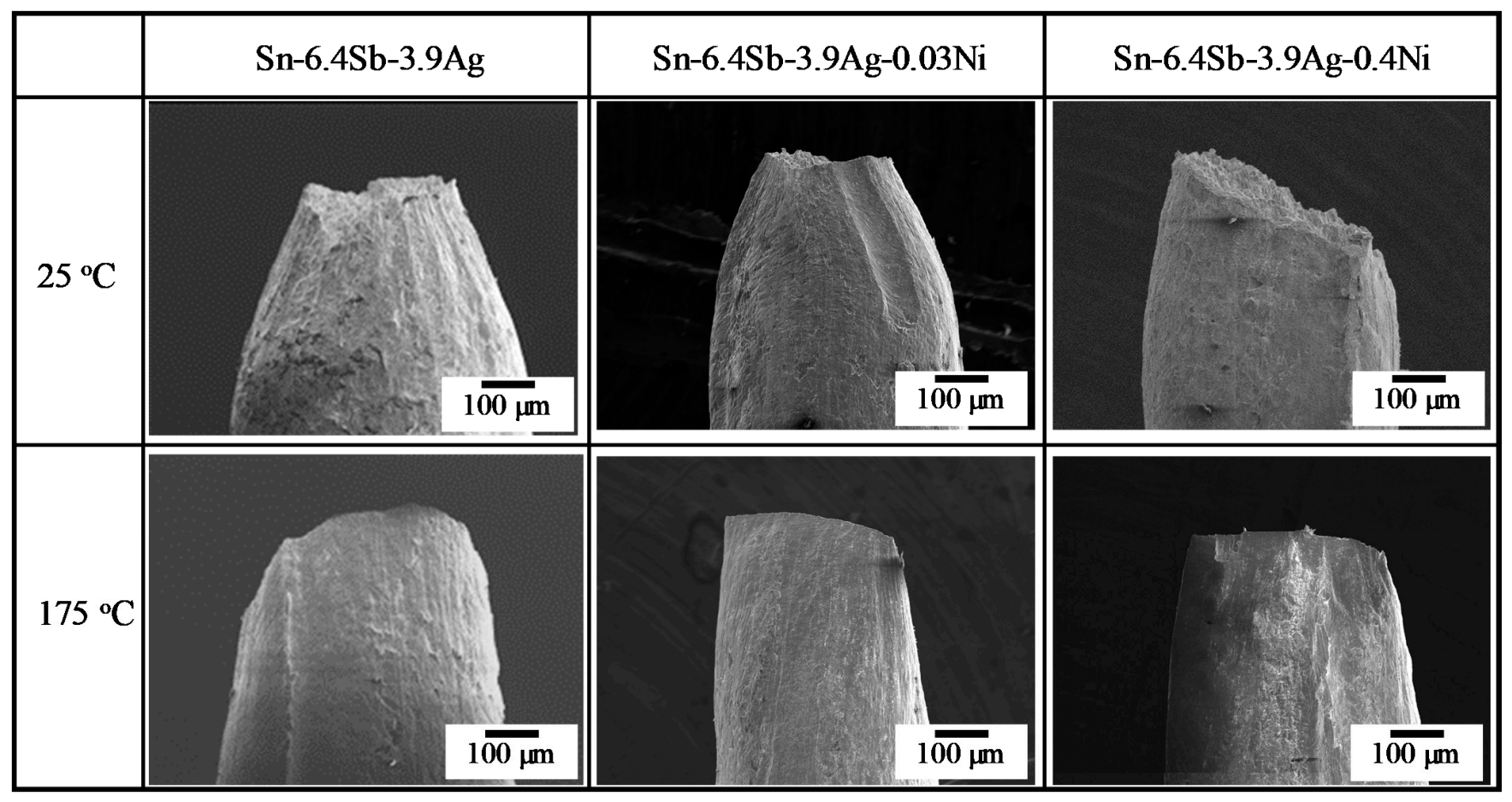

Figure 9. Secondary electron images of general views of ruptured specimens by tensile test at strain rate of $2.0 \times 10^{-1} \mathrm{~s}^{-1}$.

\subsection{Effect of Ni Addition on Fatigue Properties of Sn-6.4Sb-3.9Ag}

Figure 10 shows the relation of the inelastic strain range obtained from the hysteresis loop in the fatigue test and the number of cycle to failure obtained from the fatigue test. Since the obtained data were distributed relatively densely, the individual diagrams for each alloy are also shown in the figure. The result of Sn-6.4Sb-3.9Ag is quoted from our previous study [26]. In the low cycle fatigue test in which inelastic deformation becomes dominant, it is known that the relationship between the inelastic strain range and the number of cycles to failure follows the Manson-Coffin equation [35-37].

$$
\Delta \varepsilon_{\mathrm{p}}=\mathrm{C}_{\mathrm{p}} \cdot\left(N_{\mathrm{f}}\right)^{-\alpha}
$$

$\Delta \varepsilon_{\mathrm{p}}$ : inelastic strain amplitude, $\mathrm{C}_{\mathrm{p}}$ : fatigue ductility coefficient,

$N_{\mathrm{f}}$ : fatigue life, $\alpha$ : fatigue ductility index

As shown in Figure 10, it was found that linear regression is possible in all MansonCoffin plots, regardless of the test temperature. This means that the fatigue life does not degrade at $175^{\circ} \mathrm{C}$ in all alloys investigated, and thus, they have excellent thermal fatigue resistance. The fatigue ductility indexes of Sn-6.4Sb-3.9Ag and Sn-6.4Sb-3.9Ag-0.03Ni were 0.50 , and that of $\mathrm{Sn}-6.4 \mathrm{Sb}-3.9 \mathrm{Ag}-0.4 \mathrm{Ni}$ was 0.38 . Since the $\mathrm{Ni}$ addition volume was a trace in the $\mathrm{Sn}-6.4 \mathrm{Sb}-3.9 \mathrm{Ag}-0.03 \mathrm{Ni}$, the effect of the Ni addition on the fatigue property was negligible. In addition, the hypothesis that the fatigue life of $\mathrm{Sn}-6.4 \mathrm{Sb}-3.9 \mathrm{Ag}-0.4 \mathrm{Ni}$ is superior to those of other alloys in a high-cycle fatigue area was confirmed.

The EBSD analysis result for the cracked area of Sn-6.4Sb-3.9Ag-0.4Ni formed by the fatigue test at $25^{\circ} \mathrm{C}$ is shown in Figure 11. It was found that there are fine grains in the vicinity of the crack. As described later, in Sn with high stacking fault energy, fine grains were formed by continuous dynamic recrystallization with dynamic recovery in the thermal cycle test in the temperature range from $-55^{\circ} \mathrm{C}$ to $125^{\circ} \mathrm{C}[38]$ and the fatigue test at $125^{\circ} \mathrm{C}$ [23] and $200{ }^{\circ} \mathrm{C}$ [25]. The crack progresses at the grain boundaries of fine grains with high-angle grain boundaries [23,38]. As shown in Figure 11, it was found that the grains with high-angle grain boundaries scarcely formed in the fatigue test at $25^{\circ} \mathrm{C}$. Most of the grains observed in Figure 11 have low-angle grain boundaries. These grains seem to be sub-grains formed by dynamic recovery. At $25^{\circ} \mathrm{C}$, the recrystallization 
of $\beta$-Sn grains by the rotation of sub-grains scarcely occurred due to the low temperature, thus making the formation of the grains with high-angle grain boundaries difficult. As a result, the crack progressed at the grain boundaries of fine grains with low-angle grain boundaries. An analogous analysis result was also observed in Sn-6.4Sb-3.9Ag [26] and $\mathrm{Sn}-6.4 \mathrm{Sb}-3.9 \mathrm{Ag}-0.03 \mathrm{Ni}$. There were almost no changes in the effect of the addition of $\mathrm{Ni}$ on the fatigue properties of $\mathrm{Sn}-6.4 \mathrm{Sb}-3.9 \mathrm{Ag}$ at $25^{\circ} \mathrm{C}$.

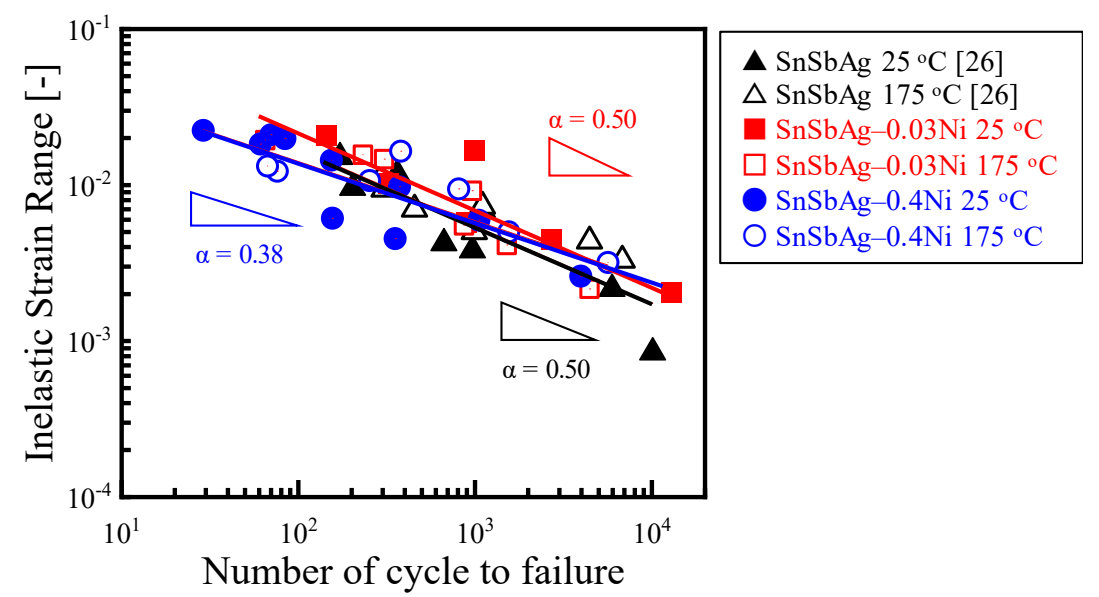

(a)

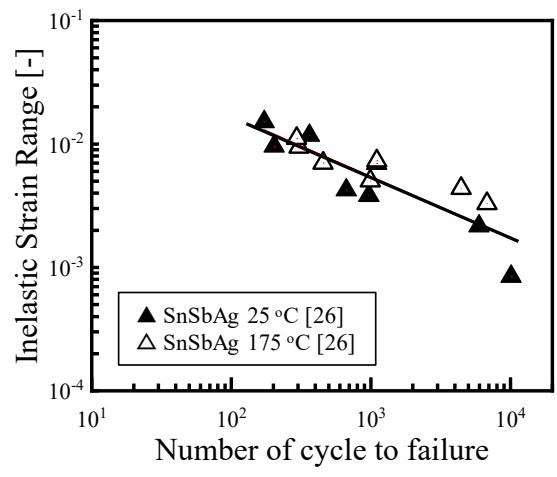

(b)

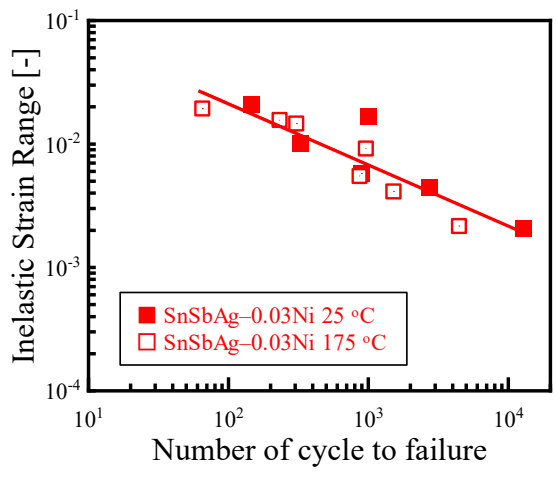

(c)

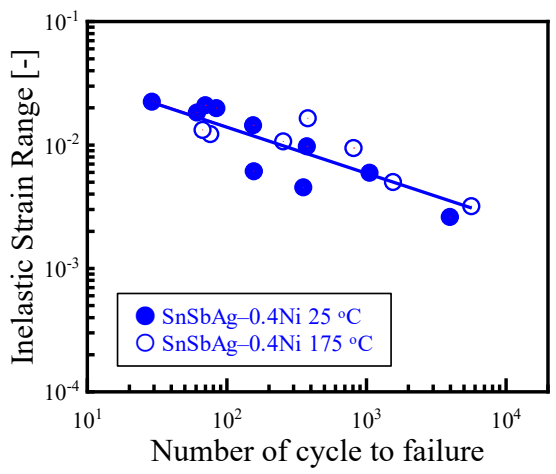

(d)

Figure 10. Fatigue properties of Sn-6.4Sb-3.9Ag [26], Sn-6.4Sb-3.9Ag-0.03Ni and Sn-6.4Sb-3.9Ag-0.4Ni. The results of all alloys are shown in (a), the results of Sn-6.4Sb-3.9Ag, Sn-6.4Sb-3.9Ag-0.03Ni and Sn-6.4Sb-3.9Ag-0.4Ni are shown in (b-d) respectively.

The EBSD analysis result for the cracked area of each alloy formed by the fatigue test at $175{ }^{\circ} \mathrm{C}$ is shown in Figure 12. As shown in Figure 12a, it was found that many fine recrystallized grains were generated in the vicinity of the crack. These fine grains were formed by continuous dynamic recrystallization $[23,38]$. Generally, in the metals such as Sn, which have high stacking fault energy, it was reported that the crack progressed at the grain boundaries of fine grains, which were generated by continuous dynamic recrystallization with dynamic recovery $[23,38]$. A similar phenomenon was observed in the fatigue damage behavior of Sn-6.4Sb-3.9Ag at $175^{\circ} \mathrm{C}$. Analogous fine recrystallized grain formation was also observed in Sn-6.4Sb-3.9Ag-0.4Ni, as shown in Figure 12c. Compared with Sn-6.4Sb$3.9 \mathrm{Ag}$, relatively finer recrystallized grains were generated, and the number of grains with high-angle grain boundaries was large in Sn-6.4Sb-3.9Ag-0.4Ni. As described in Section 3.1, the addition of $\mathrm{Ni}$ into $\mathrm{Sn}$-Sb alloys causes the formation of $\mathrm{SbNi}$ phases in the matrix [24-26]. Such SbNi phases became the origin of recrystallization, and continuous dynamic recrystallization with dynamic recovery occurred easily in $\mathrm{Sn}-6.4 \mathrm{Sb}-3.9 \mathrm{Ag}-0.4 \mathrm{Ni}$. Thus, strain energy was consumed by continuous dynamic recrystallization, and strain 
energy used by the progress of the crack reduced. As a result, the progress of the crack was slightly restrained. In addition, the crack progressed in a complex manner at the grain boundaries of fine grains, and thus the progress of the crack was also restrained. Therefore, the fatigue life of Sn-6.4Sb-3.9Ag-0.4Ni was slightly improved at $175{ }^{\circ} \mathrm{C}$.

In contrast, fine grains formation was scarcely observed in the vicinity of the crack progress area in $\mathrm{Sn}-6.4 \mathrm{Sb}-3.9 \mathrm{Ag}-0.03 \mathrm{Ni}$, as shown in Figure 12b. The crack progressed at the original high-angle grain boundary, and the grain boundary of fine recrystallized grains was generated in the vicinity of the crack. Figure 13 shows the IPF and GB maps of the whole specimen of Sn-6.4Sb-3.9Ag-0.03Ni, as shown in Figure 12b. Many low-angle grain boundaries were observed, except the original high-angle grain boundaries. As described in Section 3.1, the microstructure of Sn-6.4Sb-3.9Ag-0.03Ni is similar to that of $\mathrm{Sn}-6.4 \mathrm{Sb}-3.9 \mathrm{Ag}$, although a few $\mathrm{SbNi}$ phases and a few high-angle grain boundaries exist in the microstructure. Thus, if the crack is not generated at the original high-angle grain boundary, the crack would generate at the grain boundary of fine grains as well as Sn-6.4Sb$3.9 \mathrm{Ag}$, as shown in Figure 12a. Whether the crack generates at the original high-angle grain boundary or at the grain boundary of fine grains depends on the grain number and the orientations of the grains. In addition, it seems that the fatigue life was scarcely changed in both crack generation modes. Therefore, the fatigue properties of Sn-6.4Sb-3.9Ag-0.03Ni are almost equal to those of Sn-6.4Sb-3.9Ag. However, Figure 12b shows only the result of the crack that progressed at the original high-angle grain boundary and the grain boundary of fine recrystallized grains generated in its vicinity; therefore, further study is required to clarify the progress mechanism of the crack in Sn-6.4Sb-3.9Ag-0.03Ni.

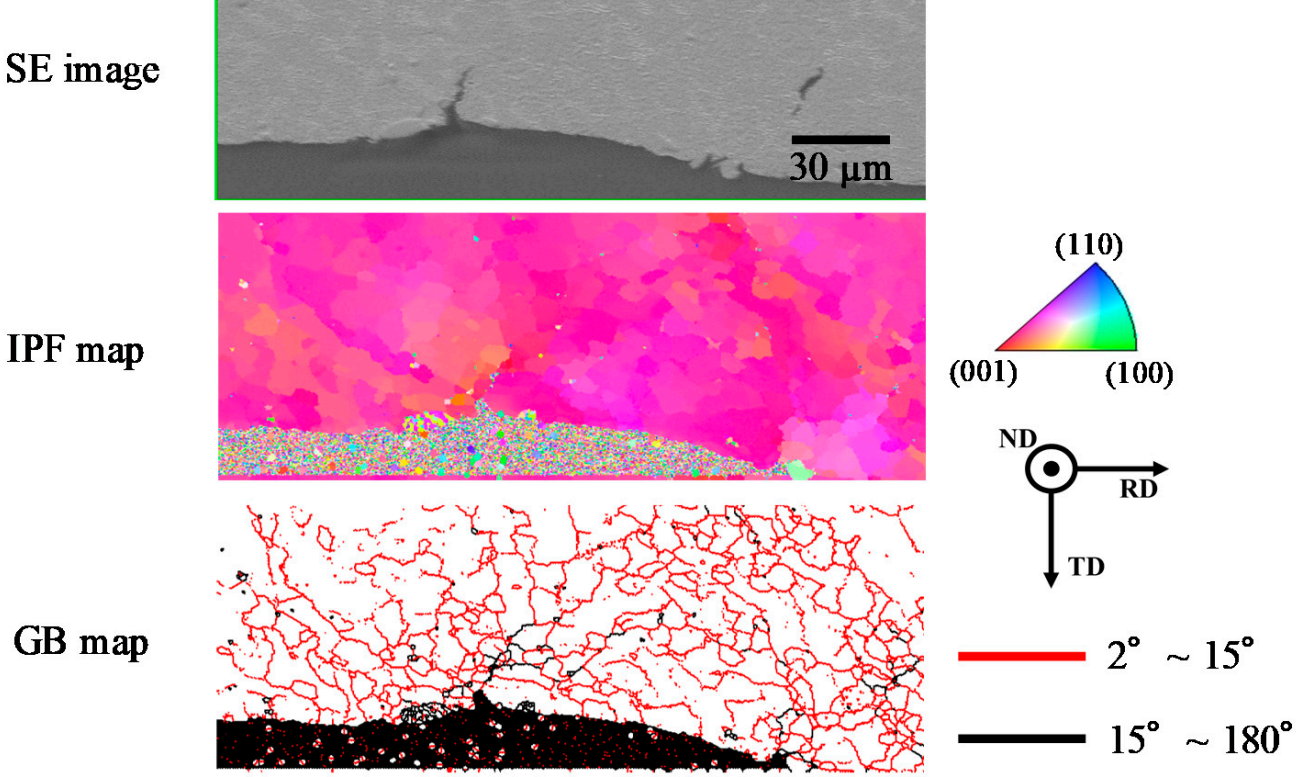

Figure 11. Result of EBSD analysis for fatigue crack area in Sn-6.4Sb-3.9Ag-0.4Ni formed by fatigue test at $25{ }^{\circ} \mathrm{C}$ (total strain amplitude: $1.0 \%, 1250$ cycles, $20 \%$ load dropped). 


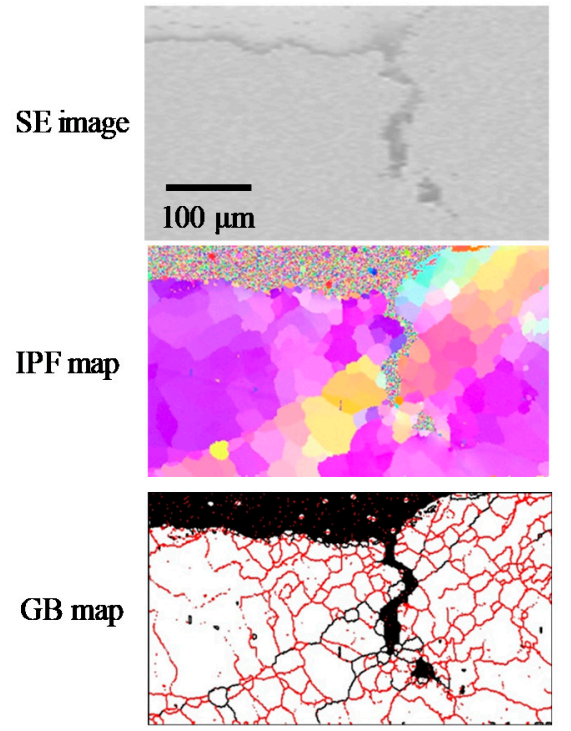

(a)

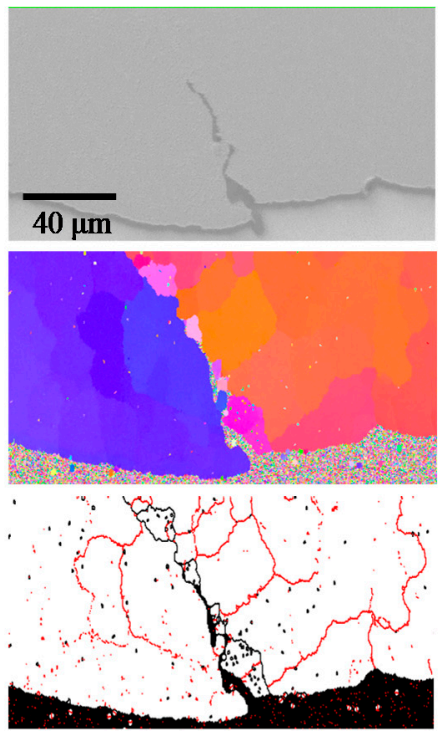

(b)

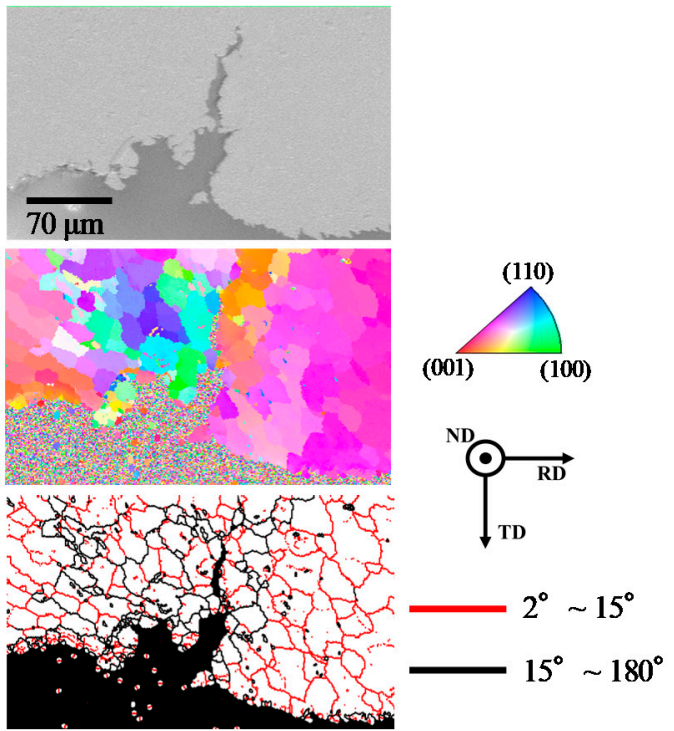

(c)

Figure 12. Result of EBSD analysis for fatigue crack areas formed by fatigue test at $175{ }^{\circ} \mathrm{C}$. (a) Sn-6.4Sb-3.9Ag (total strain amplitude: $1.0 \%, 1009$ cycles, $28 \%$ load dropped); (b) Sn-6.4Sb-3.9Ag-0.03Ni (total strain amplitude: $1.0 \%, 1127$ cycles, $22 \%$ load dropped); (c) Sn-6.4Sb-3.9Ag-0.4Ni (total strain amplitude: 1.0\%, 1057 cycles, 27\% load dropped).

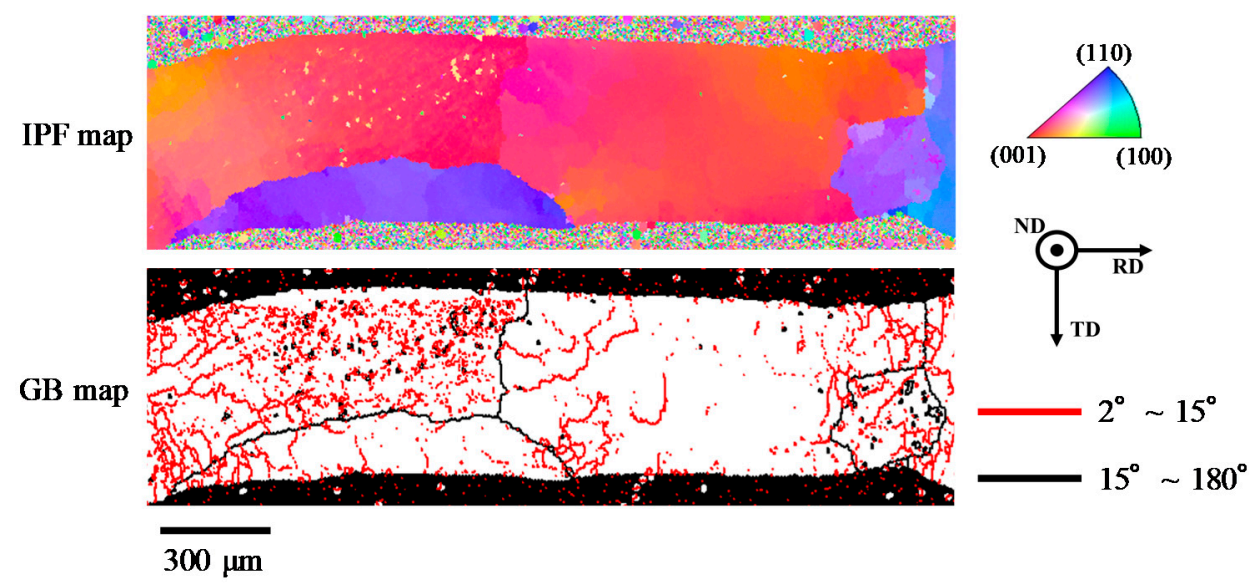

Figure 13. Inverse pole figure (IPF) and grain boundary (GB) maps of the whole specimen of Sn-6.4Sb-3.9Ag-0.03Ni, as shown in Figure 12b.

\section{Conclusions}

The effect of the addition volume of a small amount of $\mathrm{Ni}$ on the microstructures was investigated, as was that on the tensile and fatigue properties of Sn-6.4Sb-3.9Ag, using micro-size specimens. The results obtained are summarized as follows.

(1) The addition of Ni into Sn-6.4Sb-3.9Ag tends to increase the number of grains formed in the solidification process and form a high-angle grain boundary.

(2) The $0.1 \%$ proof stress of Sn-6.4Sb-3.9Ag, Sn-6.4Sb-3.9Ag-0.03Ni and Sn-6.4Sb-3.9Ag$0.4 \mathrm{Ni}$ increases with an increase in strain rate at $25^{\circ} \mathrm{C}$ and $175{ }^{\circ} \mathrm{C}$ when the strain rate is less than $2.0 \times 10^{-2} \mathrm{~s}^{-1}$. The $0.1 \%$ proof stress of $\mathrm{Sn}-6.4 \mathrm{Sb}-3.9 \mathrm{Ag}$ decreases with an increase in the $\mathrm{Ni}$ addition volume at a strain rate of $2.0 \times 10^{-1} \mathrm{~s}^{-1}$. The effect of the $\mathrm{Ni}$ addition into Sn-6.4Sb-3.9Ag on the tensile strength is negligible at $25^{\circ} \mathrm{C}$ and $175^{\circ} \mathrm{C}$. The elongation of $\mathrm{Sn}-6.4 \mathrm{Sb}-3.9 \mathrm{Ag}$ decreases with an increase in the $\mathrm{Ni}$ addition volume at $25^{\circ} \mathrm{C}$ according to the change in the fracture mode from ductile chisel point fracture to shear fracture. The effect of the addition of Ni into Sn-6.4Sb-3.9Ag on the elongation is negligible at $175{ }^{\circ} \mathrm{C}$.

(3) The relation of the inelastic strain range and the cycle to failure obtained from the low cycle fatigue test in each alloy follows the Manson-Coffin equation. The result shows 
that the fatigue life does not degrade at $175^{\circ} \mathrm{C}$ in all alloys investigated, and they have excellent thermal fatigue resistance. The fatigue life of $\mathrm{Sn}-6.4 \mathrm{Sb}-3.9 \mathrm{Ag}-0.4 \mathrm{Ni}$ is superior to those of $\mathrm{Sn}-6.4 \mathrm{Sb}-3.9 \mathrm{Ag}$ and $\mathrm{Sn}-6.4 \mathrm{Sb}-3.9 \mathrm{Ag}-0.03 \mathrm{Ni}$ in a high-cycle fatigue area. On the basis of the EBSD analysis result for the cracked area of Sn-6.4Sb-3.9Ag-0.4Ni formed by the fatigue test at $175^{\circ} \mathrm{C}$, it was found that finer recrystallized grains are generated at the cracked area by continuous dynamic recrystallization with dynamic recovery, and the crack progresses in a complex manner at the grain boundaries of fine grains, and thus the progress of the crack is restrained.

Author Contributions: Conceptualization, H.W. and I.S.; methodology, I.S.; software, M.Y. and K.M.; validation, T.K. and I.S.; formal analysis, M.Y. and K.M.; investigation, M.Y. and K.M.; resources, H.W. and I.S.; data curation, M.Y.; writing—original draft preparation, M.Y. and I.S.; writing-review and editing, I.S. and T.K.; visualization, M.Y. and I.S.; supervision, I.S.; project administration, I.S. and H.W.; funding acquisition, I.S. and H.W. All authors have read and agreed to the published version of the manuscript.

Funding: This research received no external funding.

Institutional Review Board Statement: Not applicable.

Informed Consent Statement: Not applicable.

Data Availability Statement: Data are contained within the article.

Conflicts of Interest: The authors declare no conflict of interest.

\section{References}

1. Wang, J.; Xue, S.; Zhang, P.; Zhai, P.; Tao, Y. The reliability of lead-free solder joint subjected to special environment: A Review. J. Mater. Sci. Mater. Electron. 2019, 30, 9065-9086. [CrossRef]

2. Ganesan, S.; Pecht, M. Lead-Free Electronics; John Wiley \& Sons, Inc.: Hoboken, NJ, USA, 2006.

3. Bath, J. Lead-Free Soldering; Springer: New York, NY, USA, 2007.

4. Cheng, F.; Gao, F.; Nishikawa, H.; Takemoto, T. Interaction behavior between the additives and Sn in Sn-3.0Ag-0.5Cu-based solder alloys and the relevant joint solderability. J. Alloy. Compd. 2009, 472, 530-534. [CrossRef]

5. Nai, S.M.L.; Wei, J.; Gupta, M. Influence of ceramic reinforcements on the wettability and mechanical properties of novel lead lead-free solder composites. Thin Solid Film. 2006, 504, 401-404. [CrossRef]

6. Yamashita, M.; Hidaka, N.; Shohji, I. The Effects of Ag, Ni, and Ge elements in lead-free Sn base solder alloys. In Proceedings of the 2008 10th Electronics Packaging Technology Conference, Singapore, 9-12 December 2008; pp. 582-587.

7. Zhao, J.; Mutoh, Y.; Miyashita, Y.; Wang, L. Fatigue crack growth behavior of Sn-Pb and Sn-based lead-free solders. Eng. Fract. Mech. 2003, 70, 2187-2197. [CrossRef]

8. Kariya, Y.; Niimi, T.; Suga, T.; Otsuka, M. Isothermal fatigue properties of Sn-Ag-Cu alloy evaluated by micro size specimen. Mater. Trans. 2005, 46, 2309-2315. [CrossRef]

9. Depiver, J.A.; Mallik, S.; Amalu, E.H. Thermal fatigue life of ball grid array (BGA) solder joints made from different alloy compositions. Eng. Fail. Anal. 2021, 125, 105447. [CrossRef]

10. Zhang, S.; Zhao, H.; Xu, H.; Fu, X. Accelerative reliability tests for Sn3.0Ag0.5Cu solder joints under thermal cycling coupling with current stressing. Microelectron. Reliab. 2021, 120, 114094. [CrossRef]

11. Shohji, I.; Mori, F.; Kobayashi, K.F. Thermal fatigue behavior of flip-chip joints with lead-free solders. Mater. Trans. 2001, 42, 790-793. [CrossRef]

12. Kim, K.S.; Huh, S.H.; Suganuma, K. Effects of intermetallic compounds on properties of Sn-Ag-Cu lead-free soldered joints. J. Alloy. Compd. 2003, 352, 226-236. [CrossRef]

13. Somidin, F.; Maeno, H.; Toriyama, T.; McDonald, S.D.; Yang, W.; Matsumura, S.; Nogita, K. Direct observation of the Ni stabilising effect in interfacial $(\mathrm{Cu}, \mathrm{Ni})_{6} \mathrm{Sn}_{5}$ intermetallic compounds. Materialia 2020, 9, 100530. [CrossRef]

14. Shohji, I.; Tsunoda, S.; Watanabe, H.; Asai, T.; Nagano, M. Reliability of solder joint with Sn-Ag-Cu-Ni-Ge lead-free alloy under heat exposure conditions. Mater. Trans. 2005, 46, 2737-2744. [CrossRef]

15. Kanda, Y.; Kariya, Y. Evaluation of creep properties for Sn-Ag-Cu micro solder joint by multi-temperature stress relaxation test. Microelectron. Reliab. 2012, 52, 1435-1440. [CrossRef]

16. El-Daly, A.A.; El-Taher, A.M.; Dalloul, T.R. Improved creep resistance and thermal behavior of Ni-doped Sn-3.0Ag-0.5Cu lead-free solder. J. Alloy. Compd. 2014, 587, 32-39. [CrossRef]

17. Hua, L.; Yang, C. Corrosion behavior, whisker growth, and electrochemical migration of Sn-3.0Ag-0.5Cu solder doping with In and $\mathrm{Zn}$ in $\mathrm{NaCl}$ solution. Microelectron. Reliab. 2011, 51, 2274-2283. [CrossRef]

18. Medgyes, B.; Horváth, B.; Illés, B.; Shinohara, T.; Tahara, A.; Harsányi, G.; Krammer, O. Microstructure and elemental composition of electrochemically formed dendrites on lead-free micro-alloyed low Ag solder alloys. Corros. Sci. 2015, 92, 43-47. [CrossRef] 
19. Shohji, I.; Yoshida, T.; Takahashi, T.; Hioki, S. Tensile properties of Sn-Ag based lead-free solders and strain rate sensitivity. Mater. Sci. Eng. A 2004, 366, 50-55. [CrossRef]

20. Bai, N.; Chen, X.; Gao, H. Simulation of uniaxial tensile properties for lead-free solders with modified Anand model. Mater. Des. 2009, 30, 122-128. [CrossRef]

21. Lall, P.; Zhang, D.; Yadav, V.; Locker, D. High strain rate constitutive behavior of SAC105 and SAC305 leadfree solder during operation at high temperature. Microelectron. Reliab. 2016, 62, 4-17. [CrossRef]

22. Chidambaram, V.; Hattel, J.; Hald, J. High-temperature lead-free solder alternatives. Microelectron. Eng. 2011, 88, 981-989. [CrossRef]

23. Nakajima, Y.; Ono, K.; Kariya, Y. Evaluation of fatigue crack propagation of $\mathrm{Sn}-5.0 \mathrm{Sb} / \mathrm{Cu}$ joint using inelastic strain energy density. Mater. Trans. 2019, 60, 876-881. [CrossRef]

24. Kobayashi, T.; Mitsui, K.; Shohji, I. Effects of Ni addition to Sn-5Sb high-temperature lead-free solder on its microstructure and mechanical properties. Mater. Trans. 2019, 60, 888-894. [CrossRef]

25. Kobayashi, T.; Shohji, I. Evaluation of microstructures and mechanical properties of Sn-10Sb-Ni lead-free solder alloys with small amount of Ni using miniature size specimens. Metals 2019, 9, 1348. [CrossRef]

26. Mitsui, K.; Shohji, I.; Kobayashi, T.; Watanabe, H. Effect of addition of trace Ni and Ge into Sn-Sb-Ag high temperature lead-free solder alloy on its mechanical properties. J. Smart Process. Mater. Environ. Energy 2020, 9, 133-139. [CrossRef]

27. Li, C.; Yan, Y.; Gao, T.; Xu, G. The influence of Ag on the microstructure, thermal properties and mechanical behavior of Sn-25Sb-xAg high temperature lead-free solder. Vacuum 2021, 185, 110015. [CrossRef]

28. Sato, T.; Kariya, Y.; Takahashi, H.; Nakamura, T.; Aiko, Y. Evaluation of fatigue crack propagation behavior of pressurized sintered Ag nanoparticles and its application to thermal fatigue life prediction of sintered joint. Mater. Trans. 2019, 60, 850-857. [CrossRef]

29. Park, B.-G.; Jung, K.-H.; Jung, S.-B. Fabrication of the hybrid Ag paste combined by Ag nanoparticle and micro Ag flake and its flexibility. J. Alloy. Compd. 2017, 699, 1186-1191. [CrossRef]

30. Tan, K.S.; Cheong, K.Y. Mechanical properties of sintered Ag-Cu die-attach nanopaste for application on SiC device. Mater. Des. 2014, 64, 166-176. [CrossRef]

31. Liu, X.; He, S.; Nishikawa, H. Thermally stable $\mathrm{Cu}_{3} \mathrm{Sn} / \mathrm{Cu}$ composite joint for high-temperature power device. Scr. Mater. 2016 110, 101-104. [CrossRef]

32. Watanabe, H.; Asai, T.; Hokazono, H.; Saito, S. Development on the application of the SnAgCu based lead-free solder a small amount of the added 5 elements solder of industrial electronic equipment. J. Jpn. Inst. Electron. Packag. 2011, 4, 382-389.

33. Japanese Industrial Standards. Test Methods for Lead_Free Solders_Part 1: Methods for Measuring of Melting Temperature Ranges; JIS Z 3198-1; Japanese Standards Association: Tokyo, Japan, 2014.

34. Thermo-Calc Software, 2017a; Thermo-Calc Software AB: Stockholm, Sweden, 2017.

35. Manson, S.S. Thermal Stress and Low-Cycle Fatigue; McGraw-Hill Book Company: New York, NY, USA, 1966.

36. Norris, K.C.; Landzberg, A.H. Reliability of controlled collapse interconnections. IBM J. Res. Dev. 1969, 13, 266-271. [CrossRef]

37. Shohji, I.; Orii, Y. Micro Joining and Reliability Design in Electronic Packaging (Electronic Book); Kagakujyoho Shuppan Co., Ltd.: Tsukuba, Japan, 2020.

38. Libot, J.B.; Alexis, J.; Dalverny, O.; Arnaud, L.; Milesi, P.; Dulondel, F. Microstructural evolutions of Sn-3.0Ag-0.5Cu solder joints during thermal cycling. Microelectron. Reliab. 2018, 83, 64-76. [CrossRef] 